\title{
Microtensile test in dental research. Controversial aspects in statistical analysis (experimental unit and premature failures)
}

Teste de microtração na pesquisa odontológica. Aspectos controversos na análise estatística (unidade experimental e falhas prematuras)

Ivan BALDUCCI ${ }^{1}$, Clovis PAGANI ${ }^{1}$, Daphne Câmara BARCELLOS ${ }^{1}$, Mayra CARDOSO ${ }^{1}$

1 - Institute of Science and Technology - UNESP - Univ Estadual Paulista - School of Dentistry - São José dos Campos - SP - Brazil.

\section{ABSTRACT}

Objectives: The aim of this study was to present the controversial aspects in performing inferential statistical analysis with regard to selection of the experimental unit and procedures adopted in the case of pre-test failures. Methods: Eighty-seven dissertations and theses in the field of dentistry were evaluated, for which microtensile testing was made available at three public Universities in the State of São Paulo were performed, namely: School of Dentistry, USP; School of Dentistry, Unesp (Araraquara and São José dos Campos) and the Piracicaba School of Dentistry (Unicamp). Results:Regarding the experimental unit, 34 (39.08\%) theses and/or dissertations used the "stick" and 53 (60.91\%) the "tooth/block" type. With regard to pretest failures, 9 (10.34\%) theses and/or dissertations attributed the value "0", 6 (6.89\%) disregarded the sticks, $2(2.29 \%)$ attributed the minimum value of 2 MPa, 1 (1.14\%) the minimum value of $4 \mathrm{MPa}, 1$ (1.14\%) attributed half the minimum value of the group and 68 (78.16\%) did not mention the occurrence of pretest failures. Conclusion: At present the experimental unit is considered to be the tooth (or ceramic block) and not the stick. As it relates to pre-test failures, the following are considered: attribution of a minimum bond strength value under experimental condition or in the group considered, an expressed number and percentage of cases of failures under each experimental condition; failures included in the statistical analysis and detailed explantion of how the authors performed with regard experimental designs (experimental unit and premature failures).

\section{KEYWORDS}

Microtensile; Teeth; Sticks; Premature failure; Statistical analysis.

\section{RESUMO}

Objetivo: O objetivo dessa pesquisa é apresentar aspectos controversos na condução da análise estatística inferencial quanto à seleção da unidade experimental e quanto ao procedimento adotado diante das falhas pré-teste. Método: Foram avaliadas 87 dissertações e teses na área da odontologia que realizaram ensaio de microtração disponíveis em três universidades públicas do estado de São Paulo: Faculdade de Odontologia da USP (São Paulo, Ribeirão Preto e Bauru), Faculdade de Odontologia da Unesp (Araraquara e São José dos Campos) e Faculdade de Odontologia da Unicamp (Piracicaba e Campinas). Resultados: Quanto à unidade experimental, $34(39,08 \%)$ teses e/ou dissertações utilizaram o "palito" e 53 (60,91\%) o "dente/bloco". Quanto às falhas pré-teste, $9(10,34 \%)$ teses e/ ou dissertações atribuíram valor "0", 6 (6,89\%) desconsideraram os palitos, $2(2,29 \%)$ atribuíram o valor mínimo de $2 \mathrm{MPa}, 1(1,14 \%)$ atribuiu o valor mínimo de $4 \mathrm{MPa}, 1(1,14 \%)$ atribuiu a metade do valor mínimo do grupo e $68(78,16 \%)$ não citaram a ocorrência de falhas pré-testes. Conclusão: Quanto à unidade experimental, atualmente considera-se como unidade experimental o dente (ou o bloco cerâmico) e não o palito. Quanto à ocorrência de falhas préteste, considera-se: atribuição de um valor mínimo de resistência adesiva na condição experimental ou grupo considerado; expressar o número e percentual dos casos de falhas em cada condição experimental; qual tipo de falha foi incluído na análise estatística e informar exatamente como os autores procederam em relação ao delineamento experimental (unidade experimental e falhas pré-teste).

\section{PALAVRAS-CHAVE}

Microtração; Dentes; Palitos; Falha pré-teste; Análise estatística. 


\section{INTRODUCTION}

E xperimental designs for microtensile tests in the field of Dentistry present great differences in approach in terms of statistical analysis. These differences give rise to debates and controversies, especially with regard to the validity of the conclusions presented by the authors.

The test unit or experimental unit is a fraction of the experimental material (individuals, plants, cells, animals) that can be randomly distributed among the groups being studied. In 1994, Sano et al. [1] proposed a methodology for microtensile tests in the field of dentistry, considering the "stick" unit; that is to say, the specimen to be submitted to traction, as the experimental unit. The stick unit was obtained from slices of the experimental material, the tooth. From then on researches that used the microtensile methodology followed the approach used by these researchers.

In 1999, Pashley et al. (1999) [2] explained that the methodology developed by Sano et al. [1] had the advantage of obtaining a large sample from few teeth. However, according to Camargo et al. [3], this methodology promotes a statistical flaw, because the data were treated in an independent manner (independent variable) when in truth they are dependent. An independent variable is a variable manipulated and modified by the researcher, whereas a dependent variable is a variable that the researcher wishes to measure or record. Furthermore, according to Camargo et al. [3], this statistical flaw generates consequences, such as inadequate standard errors and undue increase in the statistical power by enlarging sample size.

Moreover, in 2007, Roulet \& Van Meerbeek [4] also observed the problematic fact that various samples coming from the same tooth are not independent samples. In general, several teeth (from 2 to 3 ) have one of their tooth surfaces flattened, and the treatments are applied on these surfaces. After this, the teeth are cut into various sticks (from 4 to 16), which are submitted to tensile testing until rupture, in a universal test machine.

In the dental literature, another statistical flaw or difficulty in analysis of the data obtained has also been observed: the occurrence of pre-test failures. According to Roulet \& Van Meerbeek [4], during sample preparation, it is not rare for many sticks to fail before they can be submitted to tensile testing. According to Mine et al. (2009) [5], the occurrence of pre-test failures can be explained by traumatic preparation technique, which generates excessive stress during the preparation of sticks; or, materials with low bond strength values in the microtensile test, which present higher rates of adhesive failures, and, consequently, present high rates of pre-test failures $[4,6]$.

How does one proceed in cases of these pre-test failures? Does one attribute the value zero or a predetermined minimum value to them? The consequence of a high number of premature failures, whether or not the value zero is attributed, is probable deviation in the supposition of normality of the data obtained, and consequently, other distributions must be considered.

Therefore, there are two questions that have been the focus of our considerations: How should the experimental unit in a microtensile test be considered, by tooth/block or stick? How should one proceed in cases of premature failures?

It is necessary to conduct a study in this area in order to: observe the best approach to a statistical analysis, present safe guidance in planning and conducting the research and how to analyze its data, encourage the researcher to assimilate the basic concept of an experimental design. Therefore, the aim of this qualitativedescriptive exploratory research was to evaluate master's dissertations and doctoral theses from public universities in the State of São Paulo with regard to the different aspects of performing 
statistical analysis in microtensile tests. The hypothesis tested was: There is no difference between experimental designs (experimental unit and premature failures) for microtensile tests from public universities in the State of São Paulo.

\section{MATERIAL AND METHODS}

A total of 87 master's dissertations and doctoral theses available at three public universities in the State of São Paulo were selected, namely: FO-USP (São Paulo, Bauru and Ribeirão Preto available at http://www. teses.usp.br/), FO-Unicamp (Campinas and Piracicaba available at http://cutter.unicamp. $\mathrm{br} /$ ) and FO-Unesp (Araraquara and São José dos Campos available at http://unesp.br/cgb/ conteudo.php?conteudo $=562$ ). The search was conducted with the following criteria: All years, dissertation and/or thesis in the field of dentistry, microtensile testing performed in the methodology.

\section{RESULTS}

With regard to origin of the institution, FO-USP presented 11 (12.64\%) dissertations and/or theses [7-17]; FO-Unesp presented 30 (34.49\%) dissertations and/or theses[18-47]; and FO-Unicamp presented 46 (52.87\%) defended in the field of dentistry, which performed microtensile testing in the methodology [48-94].

\section{Experimental Unit}

Table 1 shows the number of dissertations and/or theses that used the "stick" or "tooth/ block" experimental units for statistical analysis, in the period from 1999 to 2011.

It may be observed that 34 (39.08\%) dissertations and/or theses used the "stick" as experimental units $[15,17,18,20,21,23-33,35$ $37,39-43,50,54,61,62,64,67-69,84,85]$ and $53(60,91 \%)$ dissertations and/or theses used the "tooth/block" as experimental units [4$14,16,19,22,44-49,51-53,55-60,63,65,66,70$ -
83,86-91]. All dissertations and/or theses (11) from FO-USP used the "tooth/block" as experimental units; 10 dissertations and/or theses from FO-Unicamp used the "sticks" and 36 dissertations and/or theses used the "tooth/ block" as experimental units; 24 dissertations and/or theses from FO-Unesp used the "sticks" and 6 dissertations and/or theses used the "tooth/block" as experimental units.

Table 1- Prevalence of dissertations and/or theses which, for statistical analysis, considered the experimental unit for statistical the STICK/BLOCK. Period of evaluation: 1999 to 2011

\begin{tabular}{|c|c|c|c|c|}
\hline \multicolumn{5}{|c|}{ EXPERIMENTAL UNIT - STICK } \\
\hline Year & USP-SP & UNESP & UNICAMP & TOTAL \\
\hline 1999-2001 & 0 & 1 & 1 & 2 \\
\hline 2002 & 0 & 1 & 0 & 1 \\
\hline 2003 & 0 & 2 & 5 & 7 \\
\hline 2004 & 0 & 7 & 1 & 7 \\
\hline 2005 & 0 & 2 & 1 & 3 \\
\hline 2006 & 0 & 1 & 1 & 2 \\
\hline 2007 & 0 & 1 & 1 & 2 \\
\hline 2008 & 0 & 5 & 0 & 5 \\
\hline 2009 & 0 & 1 & 0 & 0 \\
\hline 2010 & 0 & 3 & 0 & 3 \\
\hline 2011 & 0 & 0 & 0 & 0 \\
\hline TOTAL & 0 & 24 & 10 & 34 \\
\hline \multicolumn{5}{|c|}{ EXPERIMENTAL UNIT - TOOTH/BLOCK } \\
\hline Year & USP-SP & UNESP & UNICAMP & TOTAL \\
\hline $1999-2001$ & 0 & 0 & 1 & 1 \\
\hline 2002 & 0 & 0 & 0 & 0 \\
\hline 2003 & 0 & 0 & 5 & 5 \\
\hline 2004 & 0 & 1 & 1 & 2 \\
\hline 2005 & 2 & 1 & 9 & 12 \\
\hline 2006 & 1 & 0 & 2 & 3 \\
\hline 2007 & 3 & 2 & 6 & 11 \\
\hline 2008 & 2 & 1 & 3 & 6 \\
\hline 2009 & 1 & 0 & 6 & 7 \\
\hline 2010 & 1 & 1 & 2 & 4 \\
\hline 2011 & 1 & 0 & 1 & 2 \\
\hline TOTAL & 11 & 6 & 36 & 53 \\
\hline
\end{tabular}




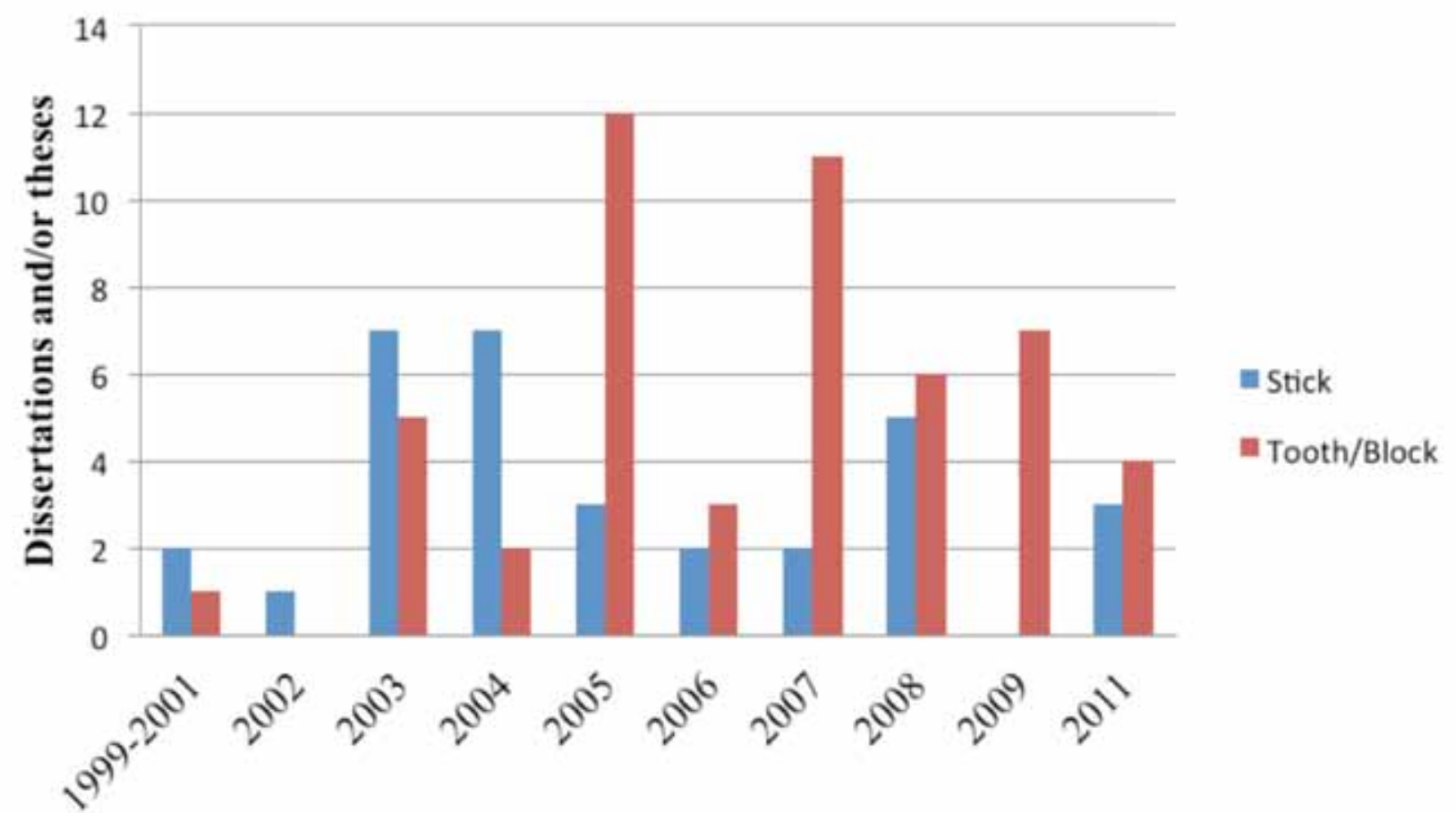

Figure 1- Prevalence of dissertations and/or theses presented by the microtensile test, according to the period evaluated (1999 to 2011) and the type of experimental unit considered in the statistical analysis.

It was observed that from 2005, the number of dissertations and/or theses that used the "tooth/block" as experimental unit was higher than the number of dissertations and/ or theses that used the "stick" as experimental unit.

\section{Pre-test Failures}

With regard to the occurrence of pre-test failures in the dissertations and/or theses, it was observed that 9 or $10.34 \%$ dissertations and/or theses (5 from FO-USP; 1 from FOUnesp; 3 from FO-Unicamp) attributed the value zero $[4,7,8,10,11,35,49,65,68] ; 6$ or $6.89 \%$ dissertations and/or theses (3 from FO-Unesp; 3 from FO-Unicamp) disregarded the sticks $[34,36,42,57,84,86] ; 2$ or $2.29 \%$ dissertations and/or theses (2 from FO-Unesp) attributed the minimum value of $2 \mathrm{MPa}$ to pretest failures [17,21]; 1 (1.14\%) dissertation and/or thesis ( 1 from FO-USP) attributed the minimum value of $4 \mathrm{MPa}$ to pre-test failures [6]; 1 or $1.14 \%$ dissertation and/or thesis (1 from FO-USP) attributed half the minimum value of MPa to pre-test failures found in the group [5]. The other 68 or $78.16 \%$ dissertations and/or theses ( 5 from FO-USP; 24 from FOUnesp; 41 from FO-Unicamp) did not mention the occurrence of pre-test failures.

\section{DISCUSSION}

\section{Experimental Unit}

The hypothesis tested was rejected for experimental unit because there was a difference between experimental design (experimental unit) for microtensile tests from public universities in the State of São Paulo.

According to the results obtained in this study (Table 1), all dissertations and/or theses from the School of Dentistry of São Paulo, Bauru and Ribeirão Preto (USP) considered the tooth as the experimental unit throughout the period of evaluation. Ten dissertations and/or theses from FO-Unicamp (Campinas and Piracicaba) used the "sticks" and 36 dissertations and/or 
theses used the "tooth/block" as experimental units, and that, Piracicaba School of Dentistry (Unicamp) considered the tooth as the experimental unit from 2008. Contrastingly, 24 dissertations and/or theses from the Schools of Dentistry of São Jose dos Campos and Araraquara (Unesp) used the "sticks", and only 6 dissertations and/or theses used the "tooth/block" as experimental units. The Schools of Dentistry of São Jose dos Campos and Araraquara (Unesp) did not clearly present the approach chosen.

Based on the aforementioned information, it could be said that there is no consensus with regard to the adoption of the "tooth" or "stick" experimental unit. The results shown in Figure 1 demonstrate that until 2004, the number of dissertations and/or theses that used the "stick" as experimental unit was higher than the number of dissertations and/or theses that used the "tooth/block" as experimental unit. Therefore, one notes the adoption of sticks in studies at the end of the 1990s, perhaps based on Shono et al., (1999)[95] and Bouillaguet et al., (2003) [96], who obtained various sticks from a few teeth (3 or 4), treating them as independent variables.

However, Figure 1 demonstrates that from 2005 the number of dissertations and/ or theses that used the "tooth/block" as experimental unit was higher than the number of dissertations and/or theses that used the "stick" as experimental unit. The correct choice in methodology was brought into use in the different schools in a similar timeframe, indicating at least a minimum comprehension of its importance by the authors and, may be based on Loguercio et al., (2005)[97], which observed that the variance of the errors (intratooth) is higher than the variance of the random effect (intertooth) variability, and concluded that 'sticks from the same tooth cannot be considered as an experimental unit, since it does not fulfill all ANOVA requirements'. In 2007, Eckert et al. [98] demonstrated that there was a correlation between beams taken from the same tooth for microtensile testing, therefore, beams obtained from the same tooth are statistically independent and wouldoverstate the statistical significance of study results.

Up to what point is this dilemma, stick or tooth/block important? When one considers the "stick" instead of the "tooth" as experimental unit, the problem of pseudoreplication occurs. Pseudoreplication takes place when a single sample is divided into various samples [99], and these samples are treated in an independent manner, when in fact, they are dependent [99]. Thus, the result obtained is not necessarily due to the factor under study (e.g., restorative technique, restorative material) but the result of inherent spatial variation among the studied teeth. Pseudoreplica is the result of the use of inferential statistics to test the effects of treatments of given experiments whose treatments are not replicated, or whose replicas are not statistically independent [100]. That is to say, pseudoreplication is not a problem of sample planning of itself only (or of sampling) but a particular combination of the experimental design (or sampling) and the respective statistical analysis that are inappropriate for testing the hypothesis of interest [101].

Therefore, when considering the stick, the design does meet the basic principle of replicas, thus, invalidates the conclusions obtained in the statistical test. When considering an unreal sample size there is (I) an increase in the statistical value of the test; (II) a reduction in the p-value obtained and (III) incorrect conclusions are established about the force of evidence against the hypothesis of nullity (H0). With pseudoreplication, it is not possible to obtain an estimate of the experimental error [100]; consequently, one cannot obtain a standard error value required for a multiple comparison test of means for any test.

When one considers the tooth/block as the experimental unit, the usual practice is to obtain the mean value of the sticks (specimens) in each tooth/block. The mean value becomes variable in analysis of the statistical test. 
There are advantages in the choice of the mean value of the tooth/block as the variable under analysis, especially when it satisfies the condition of homoscedasticity (errors that present constant variance) of the ANOVA model. One of these is that it avoids the problem of pseudoreplication, according to Hurlbert [100]. Another advantage, according to Picquelle and Mier [102], is that the probability of error Type I (error rate to reject a true hypothesis H0) virtually doesn't change in relation to the nominal value of $5 \%$, even in designs with groups of different sample sizes. That is to say, an unequal number of units (teeth/blocks) under each experimental condition, or unequal number of specimens (sticks) in each unit, or the unequal number of units under an unequal number of specimens.

For Roulet \& Van Meerbeek [4], instead of considering the calculation of the mean value of the sticks in each tooth, in the ANOVA model one could consider the factor tooth as a random effect, as De Munck et al. [103]; Farias [32], Kreidler [40] and Gamborgi et al. [104] did in their studies.

However, the factor "tooth/block" which presents a random effect does not represent a factor of interest to the researcher in terms of multiple comparison of means analysis; that is, there is no sense in performing a Tukey test, for example, for a random effect. Knowing the contribution of the random factor that could explain the total variables of the data may be useful at the stage of experimental planning. For instance, if the researcher wishes to test the effect of different treatments on the bond strength in bovine teeth, he/she will face a dilemma: How many teeth and how many measures (sticks) will be needed. What if after conducting a pilot study in six teeth, with four measurements (sticks) per tooth the researcher analyzes the data using one-way ANOVA and evaluate the components of variance with reference to the tooth and the sticks. If there is a high percentage of variance among the teeth, but not among the sticks; then there is a great deal of variance from one tooth to another. In this case, the experiment could be planned to include a larger number of teeth. If there is a high percentage of variance among the STICK, but not among the TEETH; then there is a great deal of variance among the sticks. In this case, the experiment could be planned to include a larger number of sticks per tooth $[97,98]$.

Considering the mean value of each tooth as the variable under analysis, the same result is obtained when one considers the tooth as a random factor. In practical terms of a dental research, consider the factor tooth as a random effect in the ANOVA model, as recommended by Roulet \& Van Meerbeek [4], is equivalent to the approach in relation to calculation of the mean value of the sticks in each tooth. These two approaches (unit means analysis and nested analysis) do not differ in terms of statistical test power [102].

\section{Premature Failures}

The hypothesis tested was rejected for premature failures because there is difference between experimental design (premature failures) for microtensile tests from public universities in the State of São Paulo.

Most of the dissertations and/or theses did not mention the occurrence of pre-test failures (78.16\%), $10.34 \%$ attributed the value zero $\mathrm{MPa}$, (percentage?)attributed the minimum value of $2 \mathrm{MPa}, 6.89 \%$ disregarded the sticks, $1.14 \%$ attributed the minimum value of $4 \mathrm{MPa}$ and $1.14 \%$ attributed half the minimum value of MPa to pre-test failures found in the group.

For Roulet \& Meerbeck [4], the most important data from the incidence of premature failures is to report the number and to describe how they were handled', therefore, the procedure of the majority dissertations and/or theses evaluated in this study (78.16\%), which did not mention the occurrence of pre-test failures, should be avoided.

How does one proceed in cases of these pre-test failures? According to Zander-Grande 
et al. [105], the inclusion of premature failures resulted in statistically significant difference compared to those without the inclusion of premature failures, therefore, the practice of disregarding the premature failures, excluding them from statistical analysis does not portray reality and underestimates the real bond strength [106]. For Mine et al.[5], the act of attributing the value as $0 \mathrm{MPa}$, penalizes the adhesive too severely, whilst attributed the minimum value (as 2 or $4 \mathrm{MPa}$ ) is somewhat arbitrary, because according to Reis et al. [107], specimens that de-bonded before being actually tested could present an estimated "bond strength" value that would be somewhere in the range between zero and the minimum bond strength value that was measured in that specific study'.

The goal of these approaches is to offer statistical analysis values that meet the presuppositions of a parametric approach: normality and uniformity of the residual values in the analysis of variance model, which is the prevalent test in dental research involving microtensile tests.

With regard to the dissertations and/ or tests evaluated, it was found that it was not usual practice to present the statistical analysis as justification when disregarding sticks with pre-test failure or attributing value zero. Salameh [108] eliminated all the pretest failures from statistical analysis, with the purpose of obtaining normal distribution of the data. Therefore, Salameh [108] emphasizes the supposition of normality, which is now known to be not as important as the condition of homoscedasticity, as the ANOVA models are robust.

Roulet \& Meerbeck [4] explain that if premature failure was an adhesive failure, the lowest measured value could be assigned, corroborated by some authors [107,109,110] who have attributed a predetermined minimum value, that is, the lowest microtensile value obtained within the condition or experimental group. Also, Mine et al. [5] explain that the most important is to reduce the incidence of premature failures, supporting the slices with instance gypsum or alginate during preparation of sticks, and avoiding excessive stress on it.

Therefore, the following strategies are the contemporary trend in the case of premature failures: (I) attribution of a minimum bond strength value, within the values of the sticks actually tested under the experimental condition or the group considered; (II) reporting of the number and percentage of cases of failure under each experimental condition; (III) indicating the type of failure; that is to say, if the cases considered referred to adhesive failures only, or if they also referred to cohesive and/or mixed failures and (IV) comparison of the analysis excluding the sticks with the analysis including the sticks. Finally, without knowing that "each case is a case", it is possible to express the reality of the phenomenon that occurs with valid information for a statistical analysis that must always be performed using good sense.

\section{Final Consideration}

As regards the experimental unit, 34 $(39.08 \%)$ theses and/or dissertations used the "stick" and 53 (60.91\%) the "tooth/block" type. With regard to pre-test failures, 9 (10.34\%) theses and/or dissertations attributed the value "0", 6 (6.89\%) disregarded the sticks, $2(2.29 \%)$ attributed the minimum value of 2 $\mathrm{MPa}, 1(1.14 \%)$ the minimum value of $4 \mathrm{MPa}$, $1(1.14 \%)$ attributed half the minimum value of the group and 68 (78.16\%) did not mention the occurrence of pre-test failures.

In the experimental designs in microtensile tests, contemporary practice in dentistry is to correctly consider the tooth (or ceramic, resin block, etc.) an experimental unit and not the stick. Premature failures should be attributed the lowest microtensile values obtained under the condition or experimental group in order to meet the presuppositions of a parametric approach. In addition, it is important to report the number and percentage of cases of failure 
under each experimental condition, which failures were included in the statistical analysis, and give detailed report on how the authors performed experimental designs (experimental unit and premature failures).

\section{REFERENCES}

1. Sano H, Shono T, Sonoda H, Takatsu T, Ciuchi B, Carvalho R et al. Relationship between surface area for adhesion and tensile Bond strength - evaluation of a micro-tensile bond test. Dent Mater 1994; 10(4) 236-240

2. Pashley DH, Carvalho RM, Sano H, Nakajima M, Yoshiyama M, Shono Y, Fernandes CA, Tay F. The microtensile bond test: a review. J Adhes Dent. 1999 Winter;14):299-309.

3. Camargo MA, Silveira BL, Delfino CS, Zaroni WCS, Matos AB. Microtensile bond test: a literature overview [In Portuguese]. J Healt Sci Inst 2007; 25(3) 313-8.

4. Roulet, Van Meerbeek B. Statistics: a nuisance, a tool, or a must? J Adhes Dent 2007; 9(3) 287-288.

5. Mine A, De Munck J, Cardoso MV, Van Landuyt KL, Poitevin A, Kuboki T, Yoshida Y, Suzuki K, Lambrechts P, Van Meerbeek B. Bonding effectiveness of two contemporary self-etch adhesives to enamel and dentin. J Dent. 2009 Nov;37(11):872-83.

6. Leloup G, D'Hoore W, Bouter D, Degrange M, Vreven J. Metaanalytical review of factors involved in dentin adherence. $\mathrm{J}$ Dent Res. $2001 \mathrm{Jul} ; 80(7): 1605-14$.

7. Sadek FT. Influence of methodological parameters on microtensile test. Scanning electron microscopy and bond strength measurements. São Paulo [ Thesis] Faculdade de Odontologia, Universidade de São Paulo, USP; 2005.

8. Alves FBT. Influence of sound or caries-affected dentin on the bond strength of adhesive systems and glass ionomer cements in primary teeth an in vitro study São Paulo. [Thesis]. Faculdade de Odontologia, Universidade de São Paulo, USP;2010.

9. Ramires-Romito ACD. Micro-tensile bond strength of sealant and adhesive systems applied on occlusal surfaces of primary molars. São Paulo. [Thesis]. Faculdade de Odontologia, Universidade de São Paulo, USP; 2005.

10. Peixoto LFS. Influence of dental fluorosis on the bond strength of adhesive system to enamel São Paulo. [Thesis]. Faculdade de Odontologia, Universidade de São Paulo, USP; 2006.

11. Castellan CS. Evaluation of microtensile, push-out and pull-out bond strength tests in the adhesion of fiber posts to intraradicular dentin. Finite element analysis and confocal microscopy. São Paulo [Dissertation]. Faculdade de Odontologia, Universidade de São Paulo, USP; 2007.

12. Sanada JT. Evaluation of the resistance and modulus of elasticity of bone mineralized and desmineralized for the tests of microtensile. Bauru, [Dissertation]. Faculdade de Odontologia de Bauru, USP; 2007.

13. Mendonça Neto T. Microtensile bond strength of the post-resin / resin cement/ root dentin, varying resin cement, dentin bonding system and term water storage.São Paulo, [Thesis]. Faculdade de Odontologia, Universidade de São Paulo, USP; 2007.
14. Bonifacio CC. Bond stregth of glass-ionomer cements to dentin: microtensile x microshear. São Paulo. [Dissertation]. Faculdade de Odontologia, Universidade de São Paulo, USP; 2008.

15. Galafassi D. In vitro evaluation of systems on microtensile bond strength to orrogated dentin with endodontic solutions. Adhesive interface degradation influenceRibeirão Preto. [Dissertation]. Faculdade de Odontologia de Ribeirão Preto, USP; 2009.

16. Lago AN. Adhesion to the bleached enamel surface: in vitro assessment through microtensile São Paulo. [Dissertation] Faculdade de Odontologia, Universidade de São Paulo, USP; 2009.

17. Salazar Y. Bond strength between layers of silorane e mathacrylate-based composites. Bauru. [Dissertation]. Faculdade de Odontologia de Bauru, USP; 2011.

18. Amaral R. Bond strength of a resin cement to a feldspathic ceramic:tensile bond strength, contact angle and ph after different ceramic surface conditionings. São Jose dos Campos. [Dissertation]. Faculdade de Odontologia de São José dos Campos - UNESP; 2008

19. Barbosa SH. Effect of two surface conditioning bond strength of nanofill composite repair before and after aging conditions. São Jose dos Campos. [Thesis]. Faculdade de Odontologia de São José dos Campos - UNESP; 2007.

20. Barca DC. Influence of ceramic thickness, polymerization time and the type of cement on the bond strength between feldspathic ceramic and dentin. São Jose dos Campos. [Dissertation]. Faculdade de Odontologia de São José dos Campos - UNESP; 2010.

21. Castro HL. Influence of Y-TZP Ceramic Treatment and Different Resin Cements on Bond Strength to Dentin. [Dissertation]. Faculdade de Odontologia de São José dos Campos - UNESP; 2010.

22. Michida SMA. Effect of the surface treatment of indirect composite resin on bonding to a resin cement by microtensile bond strength. São Jose dos Campos. [Dissertation] Faculdade de Odontologia de São José dos Campos - UNESP; 2007.

23. Passos SP. Bonding and conversion degree: effect of ceramic and resin luting agent. São Jose dos Campos.. [Thesis]. Faculdade de Odontologia de São José dos Campos - UNESP; 2010.

24. Vanderlei AD. Durability bond strength between a feldsphatic ceramic and resin cement:effect of the type of adhesive and of the resin cement. São Jose dos Campos, [Dissertation]. Faculdade de Odontologia de São José dos Campos - UNESP; 2008.

25. Fernandes Júnior VVB. Evaluation of bonding on microtensile a resin cement auto-conditioning (self-adhesive) on enamel and dentin: effects dental aging and conditioning: in vitro study. São Jose dos Campos, [Dissertation]. Faculdade de Odontologia de São José dos Campos - UNESP; 2010.

26. Arouca SE. Evaluation of the influence of contamination in human dentin with saliva and blood in accession process using microtensile test. Araraquara. [Thesis] Faculdade de Odontologia de Araraquara - UNESP; 2004.

27. Azevedo ER. Ultimate tensile strength and bond strength to dentin of glassionomer, after ultrasonic setting and different periods of storage Araraquara. Dissertação (Mestrado). Faculdade de Odontologia de Araraquara - UNESP; 2008.

28. Calixto AL. Analysis "in vitro" of the bond strength of composite resins in Class II cavities, through microtensile test. Effect of different restorative techniques. Araraquara. [Thesis]. Faculdade de Odontologia de Araraquara - UNESP; 2003. 
29. Castro FLA. Micro-tensile bond strength of composite to Nd:YAG laser irradiated dentin. Araraquara. [Thesis]. Faculdade de Odontologia de Araraquara - UNESP; 2004.

30. Faria RP. Bond strength of ceramic at cement agent. MicroTensile test and scannig electron microscopy analysis. Araraquara [Thesis]. Faculdade de Odontologia de Araraquara - UNESP; 2004

31. Faria RP. In vitro avaliation of bond strength of ceromer at resin cement, by the Micro-Tensile test. Effect of different surface treatments.. Araraquara. [Dissertation]. Faculdade de Odontologia de Araraquara - UNESP; 2001.

32. Farias CLC. Evaluation of microtensile bond strength after dentin deproteinization. Efect of different adhesive systems. Araraquara. [Dissertation]. Faculdade de Odontologia de Araraquara - UNESP; 2004.

33. Freitas CRB. Evaluation of immediate hybridization on microleakage and TBS in indirect composite resin restorations Araraquara. [Dissertation]. Faculdade de Odontologia de Araraquara - UNESP; 2004.

34. Freitas CRB. Evaluation of bond strength of indirect restorations to dentin. Effect of provisional cementation and dentin cleaning methods. Araraquara. [Thesis]. Faculdade de Odontologia de Araraquara - UNESP; 2008.

35. Gois AM. Bond strenghts of composite repairs - surface treatment with diamond burs, abrasion with alumium oxide particles and Er:YAG laser. Araraquara,. [Dissertation]. Faculdade de Odontologia de Araraquara - UNESP; 2004.

36. Hebling J. Adhesive performance of dentin bonding agents applied in vivo and in vitro. Effect of intrapulpal pressure and dentin depth. Araraquara. [Teshis (Full Professor)]. Faculdade de Odontologia de Araraquara - UNESP; 2003.

37. Jacques P. Adhesion to dentin after mechanical or chemical removal of carious tissue. Araraquara. [Thesis]. Faculdade de Odontologia de Araraquara - UNESP; 2005.

38. Jacques P. Microtensile bond strength of a self-etching primer and a one-step smear layer removing system to dentin treated with different conditioners. Araraquara. [Dissertation]. Faculdade de Odontologia de Araraquara - UNESP; 2002.

39. Kina JF. Influence of the smear layer and the condition of treatment of dentin (in vivo and in vitro) on the bond strength. Araraquara. [Dissertation]. Faculdade de Odontologia de Araraquara - UNESP; 2004.

40. Kreidler MAM. Dentin tensile bond strength evaluation of onebottle adhesive system using different curing devices. Araraquara. [Dissertation]. Faculdade de Odontologia de Araraquara - UNESP; 2004.

41. Malta DAMP. Bond strength of an adhesive system irradiated with Nd:YAG laser in dentin treated with Er:YAG laser. Araraquara. [Dissertation]. Faculdade de Odontologia de Araraquara - UNESP; 2007.

42. Mazur RF. Evaluation of adhesive strength on dentin under different adhesive systems by microtensile test and sem. Araraquara,. [Thesis]. Faculdade de Odontologia de Araraquara - UNESP; 2003.

43. Ricci HA. Influence of the substrate, permanent and primary teeth, and the application of chlorhexidine on the bond strength of adhesive systems to dentin. Araraquara. [Dissertation]. Faculdade de Odontologia de Araraquara - UNESP; 2008.
44. Roperto RC. Evaluation of the cementing non-metal intraradicular pins on dentin using self-adhesive resin cements.Araraquara. [Thesis]. Faculdade de Odontologia de Araraquara - UNESP; 2007.

45. Sanabe ME. Effect of a matrix metalloproteinase inhibitor on the production and stability of resincaries affected dentin bonds. Araraquara. [Thesis].Faculdade de Odontologia de Araraquara UNESP; 2009.

46. Vasconcellos WA. Analysis of the influence of different surface treatment of ceramic systems in adhesive bond strength. Araraquara. [Thesis].Faculdade de Odontologia de Araraquara UNESP; 2005.

47. Xavier CCG. "In vitro" evaluation of the bond strength of composite resin to dentin treated with differents types of adhesives systems. Araraquara. [Thesis]. Faculdade de Odontologia de Araraquara UNESP; 2005.

48. Aguiar TR. Self-adhesive resin luting: effect of curing mode on degree of conversion, biaxial flexure strength and bond strength to dentin. Piracicaba. [Dissertation]. Faculdade de Odontologia de Piracicaba, Unicamp; 2009.

49. Alexandre RS. The influence of temperature of three adhesive systems on bonding to ground enamel. Piracicaba. [Dissertation]. Faculdade de Odontologia de Piracicaba, Unicamp; 2009.

50. Almeida JB. Microtensile bond strength, thickness and type of hybrid fault with dentin adhesive systems in human. Piracicaba. [Thesis].Faculdade de Odontologia de Piracicaba, Unicamp; 2005.

51. Almeida JCF. Resin-dentin bonding durability : effect of dentin moisture on bond strength mediated by experimental primers. Piracicaba. [Thesis].Faculdade de Odontologia de Piracicaba, Unicamp; 2009 .

52. Amaral CM. Influence of polymerization techniques on microleakage of composite resins, microhardness, crack formation and resistance to microtensile. Piracicaba. [Thesis].Faculdade de Odontologia de Piracicaba, Unicamp; 2003.

53. Andrade OS. Marginal adaptation and microtensile fixed indirect restorations in dentin treated with adhesive and composite resin with low viscosity. Piracicaba. [Thesis].Faculdade de Odontologia de Piracicaba, Unicamp; 2003.

54. Arrais CAG. Effect of different activation modes on the degree of conversion, tensile bond strength and interfacial morphology of dual-cured cementing systems used in indirect composite restorations. Piracicaba. [Thesis]. Faculdade de Odontologia de Piracicaba, Unicamp; 2006.

55. Bertaglia PC. Evaluating the bond strength and conversion degree using the silorane composite in association with self-etch and etch \& rinse adhesive system. Piracicaba. [Dissertation]. Faculdade de Odontologia de Piracicaba, Unicamp; 2003.

56. Borges BCD. Effect of the casein phosphopeptide-amorphous calcium phosphate associated to adhesive procedures on bond strength of a pit and fissure sealant. Piracicaba. [Dissertation]. Faculdade de Odontologia de Piracicaba, Unicamp; 2010.

57. Caldo-Teixeira AS. Evaluation of the union composite / dentin as a function of time of etching and bonding agent in primary teeth. Piracicaba. [Dissertation]. Faculdade de Odontologia de Piracicaba, Unicamp; 2003.

58. Carvalho FG. Chemical, microbiological and mechanical analysis of adhesive system containing antibacterial monomer and fluoride 
bonded to dentin. Piracicaba. [Thesis]. Faculdade de Odontologia de Piracicaba, Unicamp; 2009.

59. Villalpando KT. Use of proteins of enamel matrix derivatives (Emdogain ) in the treatment of intra-bony defects. Long-term clinical and radiographic study. Piracicaba. [Thesis]. Faculdade de Odontologia de Piracicaba, Unicamp; 2003.

60. Cavalcante LMA. As the adhesive restorative techniques can influence the quality of aesthetic restorations: evaluation of microhardness, microleakage and bond strength. Campinas. [Dissertation]. Universidade Estadual de Campinas, Unicamp; 2005.

61. Cavalcanti AA. Bond strength in the cervical wall of class II restorations submitted to thermal and mechanical stress: effect of adhesive system and the use of low-viscosity composite. Campinas. [Dissertation]. Faculdade de Odontologia de Campinas, Unicamp; 2005.

62. Cavalli V. Influence of different formulations of bleaching agents on enamel and dentin physical and chemical properties. Piracicaba. [Thesis]. Faculdade de Odontologia de Piracicaba, Unicamp; 2007.

63. Chaves P. Influence of surface treatment of the dentin substrate in the tensile strength of adhesive systems. Piracicaba. [Dissertation]. Faculdade de Odontologia de Piracicaba, Unicamp; 2001.

64. Costa AR. Chemical degradation of adhesive materials bonded to dentin substrate: mechanical and micromorphologic analysis. Piracicaba. [Dissertation]. Faculdade de Odontologia de Piracicaba, Unicamp; 2009.

65. Dametto FR. In vitro evaluation of the influence of chemical substances auxiliary to the endodontic treatment on the nanoleakage, bond strengths and cohesive strengths of the pulp chamber dentin. Piracicaba. [Thesis]. Faculdade de Odontologia de Piracicaba, Unicamp; 2006.

66. Di Francescantonio M. Effect of viscosity and activation mode on the bond strength to dentin, conversion degree and biaxial flexure strength and modulus of dual resin cements. Piracicaba. [Dissertation]. Faculdade de Odontologia de Piracicaba, Unicamp; 2009

67. Di Hipólito V. Effect of self-etching adhesives on intact and ground enamel. Piracicaba. [Dissertation]. Faculdade de Odontologia de Piracicaba, Unicamp; 2005

68. Erhardt MCG. Influence of the degree of mineralization of the dentin in the resistance to adhesive systems of three microtensile. Piracicaba. [Dissertation]. Faculdade de Odontologia de Piracicaba Unicamp; 2003.

69. Erhardt MCG. Long-term analysis of microtensile, nanoleakage and morphologic pattern of hybrid layers promoted by different self-etching bonding agents to normal and caries-affected human dentin. Piracicaba. [Thesis]. Faculdade de Odontologia de Piracicaba, Unicamp; 2005

70. Garcia, RN. Evaluation of bond strength of adhesive systems and resin cements to dentin and restorative composites. Piracicaba. [Thesis]. Faculdade de Odontologia de Piracicaba, Unicamp; 2006.

71. Gianini M. Effect of density and area occupied by dentinal tubules in the bond strength. Piracicaba. [Thesis]. Faculdade de Odontologia de Piracicaba, Unicamp; 1999.

72. Gomes FM. Evaluation of microtensile bond strength of the union of adhesive systems to dentin with and without previous blasting of aluminum oxide and after different periods of storage. Piracicaba. [Thesis]. Faculdade de Odontologia de Piracicaba, Unicamp; 2004.
73. Gonçalves LS. Microtensile bond strength of adhesive systems as a function of collagen removal in bovine teeth. Campinas. [Dissertation]. Universidade Estadual de Campinas, Unicamp; 2007.

74. Komori, PCP. Effect of clorhexidine digluconate on the bond strength of etch-and-rinse adhesives to normal/caries-affected dentin. Piracicaba,. [Dissertation]. Faculdade de Odontologia de Piracicaba, Unicamp; 2007.

75. Lima ACMR. Bond strength and morphologic characterization of crown and root dentine treated with adhesive systems. Piracicaba. [Dissertation]. Faculdade de Odontologia de Piracicaba, Unicamp; 2007.

76. Menezes MJL. Bond strength evaluation of light, self and dualcured adhesive systems for indirect composite restorations. Piracicaba. [Dissertation]. Faculdade de Odontologia de Piracicaba, Unicamp; 2005

77. Menezes MS. Surface treatment protocol of fiber-glass with peroxide hydrogen. Piracicaba. [Thesis]. Faculdade de Odontologia de Piracicaba, Unicamp; 2009

78. Mitsui FHO. Influence of thermal and mechanical load cycling on bond strength of Class II composite resin restorations using three adhesive systems. Piracicaba. [Thesis]. Faculdade de Odontologia de Piracicaba, Unicamp; 2005.

79. Oliveira LV. Influence of time and storage medium in the microtensile bond strength of adhesive systems. Piracicaba. [Dissertation]. Faculdade de Odontologia de Piracicaba, Unicamp; 2008

80. Oliveira MT. Effect of alternative technologies for cavity preparation procedures for self-etch adhesive systems. Piracicaba. [Dissertation]. Faculdade de Odontologia de Piracicaba, Unicamp; 2008.

81. Peris AR. Behavior of adhesive systems with fluoride against the cariogenic challenge. Piracicaba. [Thesis]. Faculdade de Odontologia de Piracicaba, Unicamp; 2005.

82. Pezzini MMG. Resistance of microtensile two resin cements self-etching depending on the type of substrate and dental time water storage. Piracicaba. [Thesis]. Faculdade de Odontologia de Piracicaba, Unicamp; 2010.

83. Reis AF. Evaluation of bond strength, nanoleakage and physical properties of adhesive systems: a long-term study. Piracicaba. [Thesis]. Faculdade de Odontologia de Piracicaba, Unicamp; 2005.

84. Sá RBC. Evaluation of dentin sealing and bond strength of adhesive systems. Piracicaba. [Dissertation]. Faculdade de Odontologia de Piracicaba, Unicamp; 2011

85. Sacramento PA. Bonding degradation in endodontic treated permanent and primary teeth using different adhesive systems: an in vitro study. Piracicaba. [Dissertation]. Faculdade de Odontologia de Piracicaba, Unicamp; 2008

86. Santos AJS. Effect of the combination material-composite resilient on Bond strength to dentin/composite in experimental bi- and tri-dimensional models. Piracicaba. [Thesis]. Faculdade de Odontologia de Piracicaba, Unicamp; 2003.

87. Santos JN. Influence of endodontic irrigants on the bond strength of a self-etching adhesive to pulp chamber dentin. Piracicaba. [Dissertation]. Faculdade de Odontologia de Piracicaba, Unicamp; 2005.

88. Schneider R. Influence of surface treatment and conditioner in the microtensile bond strength between commercially pure titanium 
and resin cements. Piracicaba. [Thesis]. Faculdade de Odontologia de Piracicaba, Unicamp; 2003.

89. Segreto DR. Study of different photoinitiators in experimental resin cements photoactivated by two light curing units. Campinas. [Thesis]. Universidade Estadual de Campinas, Unicamp; 2009.

90. Shinohara MS. Effect of fluoride containing adhesive system on microtensile bond strength and acid challenge on dentin. Piracicaba. [Thesis]. Faculdade de Odontologia de Piracicaba, Unicamp; 2007.

91. Silva APB. Effect that elapsed time of antioxidant gel onto the bond strenght to bleached enamel. Campinas. [Thesis]. Universidade Estadual de Campinas, Unicamp; 2006.

92. Silva APB. Effect of an antioxidant agent on blond strength to human enamel treated with $10 \%$ carbamide peroxide. Piracicaba. [Dissertation]. Faculdade de Odontologia de Piracicaba, Unicamp; 2005.

93. Soeiro CRM. Microtensile bond strength evaluation of selfetching adhesive systems on enamel. Campinas. [Dissertation]. Universidade Estadual de Campinas, Unicamp; 2004.

94. Valentino TA. Effect of $\mathrm{NaOCl}$ storage on morphologic degradation of adhesive interface and bond strength in different substrates. Piracicaba. Dissertação (Mestrado). Faculdade de Odontologia de Piracicaba, Unicamp; 2007.

95. Shono Y, Ogawa T, Terashita M, Carvalho RM, Pashley EL, Pashley DH. Regional Measurement of Resin-Dentin Bonding as an Array. $J$ Dent Res 1999; 78(2) 699-705.

96. Bouillaguet $\mathrm{S}$. Microtensile Bond Strength between adhesive cements and root canal dentin. Dent Mater 2003; 19 199-205.

97. Loguercio AD, Barroso LP, Grande RH, Reis A. Comparison of intraand intertooth resin-dentin bond strength variability.J Adhes Dent. 2005;7(2):151-8

98. Eckert GJ, Platt JA. A statistical evaluation of microtensile bond strength methodology for dental adhesives. Dent Mater. 2007 Mar;23(3):385-91.

99. Stanley $L$. The problem of pseudo replication in neuroscientific studies: is it affecting your analysis? Neuroscience 2010; 111-17.
100. Hurlbert SH. Pseudoreplication and the design of ecological field experiments. Ecological Monographs 1984; 54(2) 187-211.

101. Schwarz CJ. Sample questions suitable for an introductory statistics class. Acess: feb/2012. Avaliable in: www.stat.sfu $\mathrm{ca} / \sim \operatorname{cschwarz/quest.html.~}$

102. Picquelle SJ, Mier KL. A practical guide to statistical methods for comparing means from two-stage sampling. Fisheries Research 2011; $1071-13$.

103. De Munck J, Van Meerbeek B, Yoshida Y, Inoue S, Vargas M, Suzuki $\mathrm{K}$, Lambrechts P, Vanherle G. Four-year Water Degradation of Totaletch Adhesives Bonded to Dentin. J Dent Res 2003; 82(2)136-140,.

104. Gamborgi GP, Loguercio AD, Reis A. Influence of enamel border and regional variability on durability of resin-dentin bonds. J Dent $2007 ; 35371-376$

105. Zander-Grande C, Loguercio AD, Stanislawczuk R, Martins GC, Gomes OM, Reis A. The effect of 6-month water storage on the bond strength of self-etch adhesives bonded to dentin. Am J Dent. 2011 Aug;24(4):239-44.

106. Van Meerbeek B, Peumans M, Poitevin A, Mine A, Van Ende A, Neves A, De Munck J. Review Relationship between bond-strength tests and clinical outcomes. Dent Mater 2010; 26 e100-e121.

107. Reis A, Loguercio AD, Azevedo CL, de Carvalho RM, da Julio Singer M, Grande RH. Moisture spectrum of demineralized dentin for adhesive systems with different solvent bases. J Adhes Dent 2003; 5(3) 183-92.

108. Salameh Z. Adhesion Between Prefabricated Fiber-reinforced Posts and Different Composite Resin Cores: A Microtensile Bond Strength Evaluation. J Adhes Dent 2006; 8 113-117.

109. Sarr M, Mine A, De Munck J, Cardoso MV, Kane AW, Vreven J, Van Meerbeek B, Van Landuyt KL. Immediate bonding effectiveness of contemporary composite cements to dentin. Clin Oral Inv 2010; 14(5) 569-577.

110. Beloica M, Goraccib C, Carvalho CAR, Radovicd I, Margvelashvili M, Vulicevic ZR, Ferrari M. Microtensile vs Microshear Bond Strength of Adhesives to Unground Enamel. J Adhes Dent 2010; 12 427-433.

\section{Ivan Balducci}

(Corresponding address)

Av. Eng. Francisco José Longo, n ${ }^{\circ} 777$,

Jardim São Dimas, São José dos Campos - SP

12245-000

Date submitted: 2013-02-27

email: ivan@ict.unesp.br 